\title{
ORÍGENES: A ORDEM DO MUNDO E O ACASO
}

Joāo Lupi

SÍNTESE - Defrontando-se com a questão do acaso, tal como proposto pela filosofia pagã, os pensadores cristãos sentiram-se ante um dilema: se existe 0 acaso, a ordem do mundo não é perfeita, mas, se tudo possui uma causa determinante, onde fica o livre-arbitrio? A resposta de Origenes é a mais completa e original, atestada pelos argumentos e pela terminologia utilizada; mas ela não coincide in totum com as propostas posteriores da Escolástica e do Renascimento.
ABSTRACT - In face of the problem of hazard, as it was proposed by pagan philosophers, the Christian thinkers were challenged by a dilemma: if hazard exists, then the order of the world isn't perfect; on the other hand, if all things have a determinant cause, is there yet a place for freedom? The most complete and original answer to the question was given by Origenes, testified through the arguments and the terminology used by him; however, it doesn't agree in totum with the later proposals of the scholastic and Renaissance.

\section{I - A questão do acaso e a Patrística}

1. A concepção da ordem do mundo é fundamental em todas as culturas: com ela se relacionam as questões metafísicas, dela dependem as ciências e técnicas, e dela deriva a organização política e social - quando não dependem nem derivam, servem-se dela para justificar uma situação, uma teoria, ou uma mudança.

Estudar as concepções acerca da ordem do mundo, em suas relações com os demais aspectos da cultura, é pois um trabalho fascinante, mas excessivamente amplo. Por isso o delimitamos numa questão particular - o acaso - que analisamos em vários conjuntos de autores; o que apresentamos aqui é o resumo de um desses estudos, centrado na doutrina, obras e argumentos de Orígenes.

2. A idéia de acaso é uma questão crítica para definir a ordem do mundo: aceitá-lo ou não, com que matizes e argumentos, é um ponto fundamental para se entender a racionalidade de uma cosmologia e da cultura, ou da doutrina em que ela se enquadra. Começamos portanto por perguntar: em que raciocínios radica a recusa da possibilidade do acaso real, presente no pensamento ocidental desde

\footnotetext{
Universidade Federal de Santa Catarina - UFSC.
}

\begin{tabular}{|l|l|l|c|c|c|}
\hline VERITAS & Porto Alegre & v. 42 & $\mathrm{n}^{2} 3$ & Setembro 1997 & p. 479-492 \\
\hline
\end{tabular}


Aristóteles? E como é que os cristãos adotaram ou modificaram esses raciocinios? Para os cristãos da Antigüidade Tardia o problema do acaso se colocava em termos de dilema: se o acaso existe realmente, e não é apenas fruto da ignorância do observador, a ordem do universo não é perfeita, e não há Providência divina (pronoia); mas se o acaso não existe, porque tudo o que acontece tem uma causa determinante, a ordem é perfeita e fixa, mas torna-se difícil explicar o livre arbítrio.

3. Explicamos o dilema: (a) se algo existe, ou pode existir, sem uma causa determinada ou determinável, é porque a relação entre seres e eventos não é fixa; obedeceria a normas ou regras que às vezes falham, ou que permitem exceções, $e$ portanto configurariam uma ordem vulnerável e imperfeita, que comportaria o erro em si mesma; o acaso escaparia à supervisão da Providência, que não seria perfeita nem completa, năo seria divina tal como se entendia na época; se uma falha fosse possivel, nenhuma regra garantiria a certeza; a insegurança seria constante; (b) mas se o acaso não existe, a ordem é perfeita - é o que defendiam os aristotélicos, com base nos argumentos da Física: o acaso real seria a produção de um evento sem causa; ora do nada, nada se segue, portanto uma causa nula não produz nada, e o acaso é inexistente; mas nestas circunstâncias tudo estaria determinado desde o início do mundo, a Providência seria desnecessária; e num universo assim organizado o microcosmo, que é o ser humano - como todos os filósofos aceitavam - refletiria essa ordem e essa pré-determinação: nada haveria a decidir em nenhum gesto humano e o homem deixaria de ser responsável pelos seus atos, o que contraria frontalmente a doutrina cristã da retribuição dos atos bons e maus.

4. Ao Cristianismo repugnavam ambas conclusões: tanto a de uma Providência desnecessária, ou incompleta, como a de um ser humano sem livre-arbítrio e irresponsável. Era preciso encontrar soluções para a ordem do universo e para o acaso dentro desses limites doutrinais. Sabemos que os doutores, os Santos Padres, optaram pela via de justificar o livre-arbítrio dentro de uma ordem do mundo perfeita, sem desordem. Sabemos também que, por causa dessa opção, muito mais se escreveu sobre o livre-arbítrio do que sobre a justificativa da ordem do mundo, ou da inaceitabilidade do acaso. Por isso mesmo julgamos que é conveniente rever essa argumentação em parte esquecida, e em parte tão assimilada que nem nos damos conta das razões pelas quais acreditamos num universo perfeitamente ordenado.'

\section{II - Os argumentos de Orígenes}

1. Comecemos pelos escritos da primeira fase, ou periodo de Alexandria (c.220-232). Como professor do didaskalion, a escola cristã, Orígenes teve de encarar as dúvidas de discípulos (catecúmenos) que provinham de escolas de outras religiões, muitos deles tendo estudado as filosofias gregas; foi em parte para eles que redigiu o primeiro tratado sistemático de doutrina cristã, o Peri Arxon - Acer-

A transliteração dos termos gregos para o alfabeto latino será feita do modo mais simples possivel; apenas se observe que ee corresponde à letra eta, e que $w$, está no lugar de ómega. 
ca dos Primeiros Principios - do qual só no resta a tradução latina feita por Rufino, e alguns trechos em grego conservados em antologias e citações. Foi ainda em Alexandria que redigiu os primeiros comentários à Bíblia, entre os quais o Comentário ao Gênesis. Neles encontramos as seguintes passagens, que apresentamos em resumo:

- Cada anjo tem seu dever particular, que lhe foi designado por Deus; ora o que Deus determina não é resultado do acaso, ou da sorte (fortuito, casu). Como Deus governa todas as coisas, não há lugar para o fortuito (Peri Arxon, I, 8, 1).

- Deus criou a matéria, senão ela seria algo independente e sem causa; seria absurdo que algo existisse fora de Deus, e incriado. A natureza da matéria seria resultado do acaso (fortuitam naturam); Deus teria encontrado a matéria por acidente (fortuito adfuisse; fortuito inventum est; Peri Arxon, II, 1, 4).

- Qual é a origem das diferenças entre os homens? Será o acidente (casu)? Ou o fortuito? "Mas se acreditamos nisso, não poderiamos mais acreditar que o mundo foi feito por Deus nem governado pela sua Providência" (Peri Arxon, I, 9, 5).

- Alguns filósofos supõem que o mundo está organizado deterministicamente, sem possibilidade de ação para o livre-arbitrio. Sendo assim, dizem eles, resta aceitar que "o mundo seria governado ou por movimentos imprevisiveis (fortuitis motibus), ou por um destino necessário" (Peri Arxon, III, 5, 5).

- Deus criou a matéria com a qual construiu o mundo. Se a matéria não fosse criada, Deus a teria encontrado por acidente (eutuxeekénai: um feliz encontro); "se a substância material se tornou o que é sem a Providência divina, então o que é que a Providência - se existe - teria feito que a espontaneidade natural (toû automátou) nạ̃o fizesse?" (Comentário ao Gênesis, I, ad I, 12).

- Existem espiritos que governam o mundo - uma doutrina desenvolvida pelo judaísmo, e pelo platonismo médio - ora uma vez que eles obedecem às ordens de Deus, não procedem aleatoriamente (apokleerwtikws), nem de modo casual (katà suntuxian; Comentário ao Gênesis, III, 1, 14).

2. Tendo-se afastado de Alexandria por divergências com o seu bispo, Origenes foi para Cesaréia da Palestina, onde criou uma escola e uma biblioteca, e onde pronunciou suas homilias de comentário metódico à Bíblia; seu amigo Ambrósio que havia sustentado os calígrafos e taquígrafos que copiavam as obras que Orígenes ditava e a quem o escritor não podia recusar um favor - pediu-lhe que redigisse uma refutação da obra de Celso: Contra os Cristãos; foi por isso, pouco antes de morrer, e talvez um pouco relutantemente, Orígenes escreveu o Contra Celso.

- Segundo Orígenes, Celso opinava que os fatos naturais: trovões, raios, chuvas, crescimento das plantas - seriam resultado de acontecimentos não dirigidos por Deus, mas suntuxikws; e um pouco mais adiante reforça: no entender de Celso "o encontro casual (suntuxia) de átomos é que deu origem às diversas qualidades dos seres"; e continua: para Celso não existe uma razão ordenadora (lógos texnikós) das variedades de plantas, nem uma inteligência de que derivam sua origem, mas tudo é katà suntuxían - devido à casualidade (Contra Celso, IV, 75). Orígenes considera que essa opinião é absurda, porque não leva em conta sequer 
a constância na produção de seres pelos que lhes são semelhantes - constância que denota, evidentemente, uma racionalidade na organização do mundo.

- As várias partes da terra estão entregues aos espíritos que cuidam delas; e isso não foi distribuido à sorte (apokleerwtikws), nem à terra dividida por sorteio (ws étuxe), porque isso seria absurdo e destrutivo da Providência (Contra Celso, V, 26).

- Ao falar dos poderes divinos, e de como eles se relacionam, mostra como os Céus e a Inteligência de Deus estão ligados por um propósito definido; e essa relação não é feita suntuxikws - sem razão (Homilias sobre Jeremias, 8,2).

3. Façamos uma primeira avaliação das doutrinas contidas nestes argumentos.

Quando se compreende que Deus governa todas as coisas, deduz-se que há normas, não acidentes. Mas a primeira opinião que Orígenes não aceita è a da eternidade da matéria. A matéria eterna, ou co-eterna com Deus, seria incriada, e suporia um Deus limitado em seu poder - o que equivaleria ao ateísmo, seria ímpio (asebés) e absurdo (átopon, o que não tem lugar). Mas no Peri Arxon Orígenes apresenta um conjunto teórico completo da doutrina cristã, e é interessante notar que, metodicamente, rejeita o acaso em todos os aspectos que compõem a sua cosmologia: os anjos, a matéria que é o substrato de todos os corpos, os homens, e as estrelas; no Contra Celso completa este quadro com as espécies de plantas, as chuvas e os trovões.

No texto latino as palavras mais facilmente traduzidas por acaso são: fortuito (fortuitum, fortuitis, fortunate), e por acidente (casu); nos textos em grego vemos: eutuxeekénai; ws étuxe, automátou, apokleerwtikws, e sobretudo suntuxia; seja como for que se traduzam essas palavras - encontro feliz, à sorte, espontaneamente, acontecimento imprevisível - sempre aparecem em oposição a: razão, juizo divino, Providência, feito por Deus, normas divinas, causas, previsão divina, mandamentos de Deus. Ao contrário, o que lhes vai associado é: o aleatório, o incriado, o absurdo, o acidental, o ímpio, e ainda a sorte e o medo. Aliás o recurso ao absurdo é freqüente: se for assim, é absurdo, portanto não pode ser assim.

Mas o que torna estas idéias inaceitáveis não é tanto a ordem do cosmo, quanto a ordem de Deus - não porque há uma ordem no cosmo, mas porque essa ordem é divina. $\mathrm{O}$ irregular e o desordenado não têm lugar (átopon) não porque o cosmo está ordenado, mas porque Deus se tornaria desnecessário, capaz de ser dispensado. Ao opor o acaso a outros conceitos, Orígenes enfatiza a ação divina: Seus julgamentos, Seus escritos, Seus mandamentos, Suas disposições. Não é a ordem das estrelas ou as maravilhas da vida que são invocadas por Orígenes, mas a ação da Providência no mundo. Por isso, se perguntássemos a Orígenes se o universo poderia ser governado por leis físicas (astronômicas, biológicas, etc.) diferentes das atuais, é provável que Origenes dissesse que sim, contanto que fossem leis de Deus. Mais ainda, estaria dentro da lógica das concepções origenistas que houvesse infinitas possibilidades físicas de realizar a ordem divina, embora só algumas se concretizassem em mundos físicos. 
Assim, tanto nas obras do primeiro período, como nas de Cesaréia, as caracteristicas principais são as mesmas: (a) pouco interesse na questão física, cujo entendimento é decorrente da concepção espiritual da ordem do mundo; (b) maior interesse pela ordem espiritual, pela idéia de Providência e pela defesa do livre arbitrio; (c) rejeição decidida e até emocional da possibilidade de aceitação da desordem no mundo, ou de uma ordem não divina; (d) a colocação da questão da desordem e da não-ordem no plano da racionalidade da fé, e não no plano da racionalidade intelectual ( $a$ qual se for pura, desligada da fé, para Orígenes não faz sentido); (e) vocabulário constante e formando um conjunto coerente: fortuito, e casu, no latim; apokleerwtikws, automaton, e a base tuxee: ws étuxe, eutuxeekénai, suntuxikws, katà suntuxian; (f) uma estrutura muito semelhante de relações e oposições dessas palavras que traduzimos geralmente por uma só: o acaso.

4. Os tradutores costumam interpretar pela palavra acaso (chance, hazard, caso, fortuito, Zufall, etc.) esses termos, que na realidade incluem muitos matizes: conjunção, movido por si mesmo, escolhido à sorte, etc. Há pois uma polissemia original, que, em cada idioma moderno, convergiu para uma só palavra, o que pode significar um estreitamento teórico em relação a um sentido que na época, e no autor, era mais variado. Não há, portanto, uma equivalência perfeita no vocabulário, e pode não havê-la na doutrina que os termos definem. Além disso os termos têm uma história, que é a do seu uso, e como diria Avicena esse uso reverte para o significado do conceito simples; e essa reversão lhes dá uma ressonância, que é a da concorrência de todos os usos; a história e a ressonância vêm à mente quando a palavra é escrita; e o leitor precisa refazer essa história para reconhecer todos os significados. Enfim: o que queremos é saber o que Orígenes tinha em mente quando pensava que esses termos eram adequados para exprimir o que ele queria dizer.

Dos termos de Orígenes que são traduzidos por acaso nem todos podem ser estudados: os termos latinos (fortuito, casu) porque dependem da interpretação de Rufino; e alguns termos gregos, porque nem todos podem ser historiados.

- Apokleerwtikws (adv.): o modo de escolher ao acaso, não encontra referências em outros autores; mesmo na forma apokleerwtikós (escolhido à sorte) é de uso muito restrito; há um uso mais amplo do verbo apokleerów, e do substantivo apokleerwsis (escolha aleatória); em todos os casos se assinala que os escritores que usam o termo o referem a sem-razão, absurdo, e expressões semelhantes;

- Ws étuxe é uma expressão mais dificil ainda de referenciar, mas que encontra sua raiz no verbo tunxánw (tugxánw), que pode significar encontrar casualmente; está na composição de suntuxánw e de suntuxía, e relaciona-se com túxee: a sorte, a fortuna.

- Eutuxeekénai também está relacionado com tuxee e tunxánw; tem o sentido explícito de bom encontro, sorte feliz; há muitas variações morfológicas que lhe são próximas: eutuxeia ou eutuxia (sucesso), eutuxéw (ser feliz), eutuxées (bem sucedido), eutuxeesis (golpe de sorte), e muitos outros, sem que se encontre uma referência idêntica à de Orígenes - eutuxeekénai. 
Passemos, pois, àqueles termos que tiveram uso mais amplo: suntuxia e autómaton.

\section{III - História dos conceitos e dos argumentos}

\section{1 - O uso de suntuxia antes de Orígenes}

Encontramos o termo em onze autores, desde Teógnis (Elegias, V, 590; escrito c.530 a.C.) até ao Evangelista São Lucas. Os historiadores - Heródoto e Tucidides - e o teólogo judeu alexandrino Filon foram os que mais empregaram esta palavra. É quase sempre um substantivo que indica um acontecimento, às vezes feliz, às vezes desgraçado, geralmente só podendo ser determinada essa qualificação pelo contexto, ou por algum adjetivo que lhe está anexo.

Mas pode também referir-se a um encontro, e também neste caso o ser bom ou mau depende do contexto; assim em Aristófanes (Acamianos, 846; As Vespas, 1323) e no Evangelho de Lucas $(8,19 ; 10,31)$, ou nos Atos dos Apóstolos $(11,26)$ casos em que parece tratar-se de encontro casual, quase neutro na qualificação, $e$ em que apenas o contexto levemente se inclina para indicar boa ou má sorte. 0 fato de a conotação depender do conjunto literário faz com que a tradução seja muito variável, e por isso suntuxía tem como equivalências nas línguas modernas: feliz sucesso, horrivel acidente, calamidade, boa sorte, desgraça, circunstâncias, conjuntura, evento futuro, situação, encontro casual... Muitas vezes tem sentido claramente religioso, expresso em Teógnis (l.c.), Sófocles (Antígona, 157) Heródoto (Historia, VII, 54), e Platão (Fedro, 248c); mas, paradoxalmente, não está explícito na Bíblia (Lucas, o.c.; Macabeus, II, 8, 14), nem em Filon (Os Sonhos: I, 18, 110; I, 38, 221; II, 15; II, 21, 31, 145, 212, etc.).

Convém notar que não encontramos o uso de suntuxía: (a) no periodo aproximadamente entre 40 d.C. e 240 d.C., ou seja desde Filon até Orígenes, com exceção do Evangelista Lucas, e portanto não é usado pela Patrística anterior a Orígenes; (b) em contextos referidos ao mundo físico, ou às causas naturais do cosmo; (c) em formas adverbiais - e mesmo as formas verbais são de uso restrito, só na Bíblia; (d) em contextos de conotação filosófica; mesmo em contextos religiosos não tem formulação teórica, mas narrativa; (e) em nenhum caso há indicação de que se refira a eventos sem causa.

Suntuxía é pois um acontecimento corriqueiro da vida humana, em que existe uma certa imprevisibilidade e sorte, tão indiferente que não se sabe se é boa ou má. Porém, para lá das aparências acredita-se que há um poder divino que cuida dos destinos humanos - embora para os autores do período clássico, nomeadamente Píndaro, Aristófanes e os historiadores, a divindade pareça distante.

\section{2 - Autômatos antes de Origenes}

Em Homero (lliada, V, 749-751; VIII, 393-395; XVIII, 376) e Xenofonte (Helenica VI, 4, 6-8) fala-se de estátuas que se movem, e de portões que se abrem por si mesmos (automatoi); a maioria das estátuas animadas de que se fala nessas 
passagens, e em outras semelhantes de autores clássicos, representavam animais, e eram sempre o produto do trabalho de um deus - Hefaísto; eram portanto tidas como mágicas; os portões que se abrem por si eram portões do Olimpo, ou portas de templos, portanto num e noutro caso o autómaton não é produto de forças internas da natureza ou das coisas, ou de forças espontâneas da matéria, mas da força divina. A ambigüidade (movem-se por si, e pelos deuses) está bem expressa em duas das passagens da llíada, onde os portões primeiro são ditos autómatoi, e logo a seguir se diz que as Horas é que os movem. Aliás a figura das portas que se abrem era uma imagem literária freqüente, usada por muitos escritores: Plutarco, Dion Crisóstomo, Flávio Josefo, entre outros - mas quase sempre referindo-se a templos. Que autómatos é uma força que vem de dentro fica claro em outra passagem da Ilíada (II, 408) onde se diz que Menelau decidiu por si mesmo - autómatos - ir ao banquete de Agamemnon sem ser convidado; mas trata-se, evidentemente da vontade espontânea, e não de forças naturais.

$\mathrm{Na}$ Bíblia fala-se de frutos espontâneos dos campos (Levítico 25, 4-5); de um fogo que surgiu por si (Sabedoria, 17, 6); da terra que por si mesma frutifica (Marcos, 4, 28); e da porta da prisão que se abriu por si mesma para Pedro passar (Atos 12, 10). Os termos e expressões espontâneo, por si, sozinho traduzem automatos, automátee; mas sempre são fatos relacionados com o poder divino, que atua através da natureza, ou de um anjo; se essa relação não está expressa, ela está contida indiretamente no contexto das maravilhas que Deus opera em favor do seu Povo.

Entretanto, os discípulos de Epicuro, e nomeadamente Lucrécio no De rerum natura, baseados nas teorias dos atomistas, e apoiados no materialismo de alguns aristotélicos, defenderam a existência de forças espontâneas da matéria, dos átomos, ou da natureza, que dispensariam a intervenção divina na ordem do mundo. Os deuses, diziam, eram transcendentes demais para se imiscuir nas coisas da matéria, e felizes demais para se preocuparem com os problemas dos homens. Como acabamos de verificar, essas idéias eram desconhecidas na tradição clássica e frontalmente opostas aos pensadores de índole religiosa, principalmente aos da tradição platônica. É pois contra esses que se dirige Teófilo de Antioquia, na Carta a Antólico (escrita c.181 d.C.) ao referir-se aos que dizem "que todas as coisas são produzidas sem nenhum agente externo "- automatismón toôn pántoon einai; esses, prossegue Teófilo, são como os materialistas e os que negam a Providência.

Encontramos, portanto, três usos e significados de autómaton e seus derivados: 1. forças internas da matéria que lhe foram dadas pela divindade (de Homero até Lucas); 2. forças espontâneas e intrínsecas à matéria, independentes dos deuses (dos atomistas aos seguidores de Epicuro); 3. forças inexistentes como próprias da matéria (críticas ao atomistas e epicuristas). De qualquer modo o significado é basicamente o mesmo: no primeiro caso é acrítico, no segundo é afirmado, no terceiro é negado, o que faz com que se torne um termo qualificado por doutrinas determinadas, e portanto de uso teórico.

Os teólogos posteriores seguirão o mesmo caminho: Hipólito de Roma, na Refutação de todas as heresias (escrito c.230; I, proêmio; I, 10-11; II, 22; X, 3); e as Homilias de Clemente (mesma época; IX, 16; XI, 34; XV, 3-4), que se referem ex- 
plicitamente a Epicuro e a autómaton/ automatismós/ katà automatismón, noções que rejeitam em nome da Providência. Mas também aparece um uso de autómaton mais referido à vida humana e social, em Clemente de Alexandria (Stromata, I, 19; escrito c.198); é interessante notar que Clemente foi mestre e antecessor de Orígenes no didaskalion, e que foi ele o primeiro a relacionar automatismón com suntuxia, na recusa do acaso na História. É certo que Orígenes deve algumas idéias, métodos, e convicções a Clemente, e possivelmente também este esboço de teoria do acaso.

\section{3 - Suntuxía depois de Origenes}

Entre Pânfilo (c.250-309) e Teodoro Estudita c.759-826) encontramos suntuxía referida 33 vezes em 19 autores, todos cristãos. Podemos agrupar os significados do termo em duas direções: uma que permanece fiel ao originário, literário, sem conotações teóricas, e que se pode traduzir por encontro, encontro feliz, encontro casual; esta mesma, a partir de Basílio de Cesaréia (330-379) e das suas Regras Monásticas passa freqüentemente a ter o significado de reunião, convivência, assembléia, conversa espintual (entre monges) ; a outra direção é a que refere suntuxía ao mundo, com a conotação de acidente, encontro inesperado, fortuito, casual. Como é este segundo sentido que foi iniciado por Orígenes, prestemos-lhe atenção.

(a) Eusébio de Cesaréia (c. 263-339): Preparação para o Evangelho.

- Ao apresentar as doutrinas de Diodoro Sículo diz que esse historiador nem sequer mencionou o nome de Deus ao tratar de cosmologia, mas mostrou o arranjo do universo como se fosse algo acidental (suntuxikèen dè tina) e espontâneo (kai autómaton) (I, 7, 21).

- Expõe as diversas doutrinas dos gregos acerca da ordem do mundo, e diz que para alguns "o mundo é incriado, não foi feito por Deus, mas mantém-se de forma espontânea (automátws) e acidental (kai suntuxikws), e ainda há os que declaram que os átomos que compõem o mundo são destituídos de vida e de razão" (VII, 11, 320).

- Diz que as doutrinas dos fenícios e dos egípcios sobre a origem da vida animal "introduziram a idéia da geração espontânea (autómaton)" não apenas nos brutos, mas também no homem; segundo esses relatos, a vida brotou de uma natureza comum, "da mesma maneira fortuita" (suntuxikws) não fazendo diferença entre a vida racional e a irracional (VII, 17, 330).

(b) Dídimo o Cego (c. 313-398): Comentáno aos Salmos

- a propósito do Salmo 30, v.16, que reza: "Nas tuas mãos, Senhor, estão os meus tempos (sortes)" Dídimo comenta: nas mãos de Deus estão todos os destinos; e não se julgue que isto acontece de modo casual (oudè gár suntuxikws).

(c) Gregório de Nissa (331-395)

- Falando do governo do mundo pela Razão, argumenta que o racional deve dirigir o irracional, e o contrário seria usurpação, "como se, em resultado de uma 
distribuição arbitrária, os mesmos privilégios tivessem sido entregues por acaso (suntuxikws) a alguém [...]" (Contra Eunômio, I).

- Ao discutir os argumentos dos não-cristãos acerca da influência dos astros sobre as ações humanas e o destino, diz: "Perguntei se a causa de tais eventos era casual (suntuxikêe) sem relação com a razão, ou se era outra espécie de causa, com a qual os acontecimentos têm alguma relação" (Contra o Destino, apud PG 45, 161D, 164 A).

- Apologia sobre o Hexaemeron (apud PG 44):

"Dizer que no princípio o mundo foi feito significa que Deus fez todas as coisas, ocasiōes, causas, e poderes [...]. Seu poder e sabedoria manifestaram-se na perfeição das partes do mundo [...]. Assim o requeria a ordem natural na disposição de todas as coisas: elas não são dispostas por si mesmas (ouk automátw) nem casualmente (tini suntuxiai)" como se fosse um movimento impulsivo, desordenado e fortuito $(72 \mathrm{BC})$.

Nas coisas que Deus fez não existe ausência de razão (álogónti), nem casualidade (suntuxikón), nem espontaneidade (automáton; 73 B).

Ao tratar da criação do fogo e da luz, explica: "Moisés disse que lessas coisas] eram obra de Deus, afim de evitar que alguém interpretasse o aparecimento do fogo como se tivesse sido produzido por geração espontânea (pròs automatón) ou casualidade (suntuxian; $76 \mathrm{C}$ ).

(d) Procópio de Gaza (c.475-528): Comentário a Josué.

- Ao comentar a distribuição de terras aos israelitas, feita por Josué na assembléia de Silo, explica: "esta distribuição foi feita segundo o costume, não de modo fortuito" (ouk ws suntuxikòs); e logo adiante: ela não foi de nenhuma forma fortuita (oukun ou suntuxikws; 18,1).

Encontra-se, pois, nestes quatro autores, um uso diferenciado de suntuxía, que não só se distingue do uso literário dos demais, como se identifica com o quadro teórico no qual o empregou Orígenes: relacionado com o mundo, em associação com o termo autómaton e seus derivados, e repudiando qualquer espécie de materialismo e de desordem no cosmo, porque a vontade divina, a Providência, não o permitiria. Mas há outra particularidade nestes quatro autores: é que todos eram origenistas convictos: Eusébio, que viveu em Cesaréia da Palestina, escreveu com Pânfilo uma Apologia de Orígenes, e dedicou extensos capítulos da História Eclesiástica ao seu teólogo preferido; Dídimo o Cego, alexandrino, e mestre no mesmo didaskalion de Orígenes, imitou o estilo alegórico da exegese origenista, e tão fiel lhe foi na Teologia que foi mais tarde incluído nas condenações das doutrinas do mestre; Gregório foi mais cauteloso, mas dos três capadócios foi o mais próximo seguidor de Orígenes; e Procópio também é considerado pelos que o estudaram como um adepto das doutrinas de Orígenes.

Houve, portanto, uma escola origenista no tratamento da questão do acaso, que empregou não só o seu vocabulário típico, mas também o quadro teórico e argumentativo. 


\section{4 - Autômatos depois de Orígenes}

$\mathrm{O}$ uso deste termo e seus derivados também se pode dividir em dois sentidos: (a) o de algo que acontece por si, sem expliçação - seria o sentido não-teórico, semelhante ao sentido literário de suntuxía; e (b) o de forças próprias da matéria e dos átomos, com referência às vezes direta, outras vezes só implícita, ao epicunismo, e às idéias de eternidade da matéria, ou dos limites da Providência. No total a referência encontra-se em onze autores, dos quais quatro são desconhecidos - ou melhor, trata-se de obras espúrias, atribuídas falsamente a certos autores. $\mathrm{O}$ que é interessante notar é que dos sete autores conhecidos cinco eram leitores de Orígenes, uns para adotar suas idéias ou mesmo defendê-lo, como os já citados Eusébio, Gregório de Nissa, e Basilio; outros para combatê-lo, como Metódio de Olimpo (que quando jovem era origenista), e Máximo o Confessor; e há dois dos quais não conhecemos as inclinações doutrinárias, mas que por serem de Alexandria certamente viviam num meio que discutia Orígenes: Isidoro Pelusiota e o autor desconhecido do Diálogo atribuído a Atanásio.

Vamos exemplificar os vários significados e empregos do termo.

(a) A aplicação literária ou narrativa encontra-se em Basílio (Homilia I,7; escrita c.370) que para designar animais selvagens usa autómatois; emprego semelhante tem em Gregório (na Carta 20, de c.360) que descreve uma paisagem e fala do bosque natural (autómatos hule); há ainda outros exemplos que caracterizam um significado meramente descritivo, às vezes metafórico.

(b) Diversas passagens apenas referem autómatos como ligado à teoria epicurista e materialista, sem maiores considerações; assim é com João Malalas (Chronographia X, Graec. 251; escrita por volta de 566) onde incidentalmente diz que o imperador Nero era inclinado às doutrinas epicúreas do automatismo; e também Metódio (Acerca das coisas criadas um escrito de c.300) que refuta a idéia da eternidade ou da autogeração do universo, contrapondo-lhe a idéia de criação; outras indicações breves como estas são a de Isidoro Pelusiota (Carta IV, de c.410) e a obra Contra algumas doutrinas aristotélicas (um escrito de c.400 atribuído erradamente a Justino).

(c) Interessam-nos mais aqueles textos que expõem algum tipo de argumento contra o acaso baseado na refutação da teoria do automatismo e que são os seguintes:

- Eusébio de Cesaréia, que como já vimos refuta o epicurismo e associa suntuxía/autómatos, repete os mesmos raciocínios em outros textos seus (Preparação para o Evangelho I,8; e no Comentánio a Isaías).

- Os Diálogos atribuidos a Cesário de Nazianze (obra escrita depois de 550) é mais completo, e apresenta uma longa discussão sobre o automatismo, a partir da pergunta de supostos discípulos: porque é que se diz que não há nada que seja produzido por si mesmo? Não vemos nós o arco do céu, e como ele é perfeitamente redondo, e incriado, existindo por si mesmo? - $\mathrm{O}$ autor desenvolve amplo argumento baseado nas ilusões dos sentidos; o diálogo é interessante, mas a questão da desordem e do acaso, sendo reduzidas às ilusões de ótica, são passadas de lado. 
- Máximo o Confessor trata da ordem do mundo e da teoria do automatismo em diversas passagens (Perguntas a Talássio, escrito c.631; Artigos acerca da Caridade IV, 6 e 14; e Carta 15). É interessante que Máximo afirma que "o mal não se encontra na natureza das coisas criadas, mas no movimento incerto e irracional" ; e noutro lugar: "o mal não teve existência, e pela sua natureza nunca a terá; o mal é uma deficiência no propósito de uma ação [...] um movimento irracional com respeito à sua finalidade". Seríamos tentados a dizer que ele identifica a desordem com o mal, e o acaso como uma impossibilidade real por ser, como todo o mal, apenas uma negação de ser; mas o contexto nos diz que Máximo, como bom leitor que era do Pseudo-Dionísio, está apenas pensando no mundo como teofania, e na ordem espiritual do universo, e não no acaso, na desordem, ou na possibilidade (ou não) das falhas nas leis físicas do cosmo.

Em resumo, a análise de autómatos no seu emprego posterior a Orígenes nos diz que a doutrina do teólogo de Alexandria continuava a ser adotada pelos seus seguidores, e era conhecida de todos os estudiosos, mas que não houve desenvolvimento dos argumentos, nem novos argumentos, nem ampliação teórica da questão, ao menos no que se refere aos contextos em que foram empregados os termos principais que Orígenes usou: suntuxía e autómatos.

\section{IV - Revisão e conclusões}

1. Ao considerar a atitude daqueles que aceitam o acaso, Origenes insistiu cada vez com maior ênfase em acusá-la de ímpia, mais do que de absurda; chama Celso explicitamente de epicúreo, isto é, materialista. Sabe-se pela Carta de Gregóno (n.152) que nas aulas de Origenes os ateus e os materialistas nâo só não eram estudados como nem deviam ser mencionados, apesar de todas as demais correntes da filosofia grega (pagã) serem alvo de discussão. Contudo nos escritos julgou necessário ocupar-se deles, mas só entrou em detalhes - quanto ao atomismo, e às leis da natureza - no Contra Celso, que só escreveu porque Ambrósío, a quem muito devia, lhe pediu. Assim, pela primeira vez Orígenes apresenta aos estudiosos cristãos argumentos contra 0 acaso, que proceđem đa observação, e das teorias físicas; tais argumentos referem-se às coisas terrestres, e, acrescentando-se aos argumentos sobre as coisas celestes, completam a visão compreensiva do mundo: ele considerou a questão da ordem e do acaso no céu e na terra, nos anjos e nos homens, nas estrelas e nas plantas, nas nações e na matéria, nas tempestades e nos espíitos dos astros, enfim: na Providência e em todas as suas obras.

2. Em resumo, os argumentos podem apresentar-se deste modo:

(a) o acaso poderia ser justificado pela teoria da constituição atômica da realidade, e das forças internas e espontâneas dos átomos; mas é preciso que a veracidade desta hipótese seja demonstrada; ora isso é impossível, porque ela colide com implicações teológicas que a invalidarn; Orígenes nem se preocupa em explicar que ela é indemonstrável na prática, porque ela é absurda na teoria;

(b) as similaridades constantes nas espécies de plantas (e, supõe-se, de animais) claramente sustentam a crença de que esta constância reflete uma ordem 
intrínseca do mundo: "por isso é que nós cristãos chamamos a este mundo de nossa casa (domicilium, estia; Contra Celso, IV, 75).

(c) se a matéria existisse desde sempre, junto com Deus, então ela seria autônoma, com forças próprias, e com uma ordem independente da divina - essa era a concepção das cosmogonias anteriores à hebraica, que supunham que o caos primitivo era ordenado pelas lutas entre os primeiros deuses; mas a concepção mosaica e cristã do Deus único implica a sua identificação com um Ser Supremo e Todo Poderoso, incompativel com noções que contenham a idéia de um deus menor, que não dominasse a matéria; portanto, o Deus Criador impõe sua ordem à matéria que Ele tira do nada;

(d) os astros, os espíritos e os anjos, são também criaturas que obedecem aos mandamentos divinos, e que por isso se enquadram dentro da mesma ordem providencial do mundo; se os astros, considerados seres animados superiores (não animais) como toda a Antigüidade aceitava, pudessem ter vontade própria, ou se os anjos pudessem pecar, como os demônios pecaram desobedecendo, então, diria Orígenes (mas não está explícito) a Providência corrigiria os resultados destes atos, não permitindo que sua obra decaísse da perfeição limitada que lhe impusera.

Revendo os argumentos e comparando-os com a histónia dos principais termos que ele emprega, podemos concluir assim acerca da doutrina de Orígenes sobre a ordem do mundo e o acaso:

1. Orígenes criou uma teoria própria sobre a questão do acaso, atestada por um vocabulário original, específico, e coerente, por uma argumentação completa, embora dispersa, por um quadro teórico consistente, e pela continuidade fiel entre os seus seguidores; essa teoria sobre o acaso foi a primeira definida dentro de um sistema teológico-filosófico cristão e teve influência no desenrolar dos debates medievais.

2. A concepção de Orígenes acerca do acaso não coincide totalmente com o tratamento que lhe foi dado posteriormente (sobretudo a partir da Escolástica e do Renascimento) e do qual somos herdeiros: a concepção origenista é mais ampla e flexível, o que é atestado pela variedade de termos e expressões traduziveis pelo termo único acaso; e pela não dependência estrita das teorias físicas, mas pela dependência de teorias metafísicas e teológicas que permitem aplicações práticas variáveis.

Sendo assim, a concepção origenista do acaso e da ordem do mundo, flexivel e não presa a um objetivismo realista, é mais interessante no mundo da paraconsistência e da não-objetividade das leis da Física, do que as concepções posteriores que se desenvolveram entre a Escolástica e o Positivismo.

\section{Bibliografia}

Esta é uma bibliografia reduzida: a pesquisa foi feita no Boston College, sob orientaçāo do Institute of Medieval Philosophy and Theology, com bolsa do CNPq; a bibliografia então (1995) consultada foi muito vasta e não pode constar toda aqui, mas pode ser indicada a quem o desejar. 


\section{Obras de referência}

ARNDT, William F. \& GINGRICH, F.Wilbur. A Greek-English Lexicon of the New Testament and other Early Christian Literature. (Tradução e adaptação do Dicionário de Walter Bauer). Chicago/Cambridge U.P., 1963, 4a ed, 6a impr.

BERARDINO, Angelo Di. Encyclopedia of the Early Church. Tradução de Adrian Walford do original Dizionario Patristico e di Antichitá Cristiane, Marietti, 1984.

Oxford U.P., Nova Iorque, 1992.

CHANTRAINE, Pierre. Dictionnaire Étymologique de la Langue Grecque. Histoire des Mots. Klincksieck, Paris, 1968, 2 vols.

GEERARD, Mauritius. Clavis Patrum Graecorum. Brepols - Turnhout, 1974-80, 4 vols.

LAMPE, G.W.H. (ed). A Patristic Greek Lexicon. Clarendon, Oxford, 1961.

LIDDELL, Henry George, \& SCOTT, Robert. A Greek-English Lexicon. (Clarendon Press 1843). Revista e aumentada por Sir Henry Stuart Jones \& Roderick McKenzie.Clarendon Press, Oxford, 1968.

LOGOS. Enciclopédia Luso Brasileira de Filosofia. Verbo, Lisboa/São Paulo, 1989.

New Catholic Encyclopedia. McGraw Hill, Washington, 1967, 15 vols.

QUASTEN, Johannes.Patrology. The Newman Press, Westminster, 1950-60, 4 vols. idem na tradução espanhola: Patrologia, BAC, Madrid, 1984.

SOPHOCLES, E.A. Greek Lexicon of the Roman and Byzantine Periods (from B.C.146 to A.D.1100). Harvard U.P., Cambridge, 1914.

STEPHANUS (Henni Estienne). Thesaurus Graecae Linguae. (1572). Akademische D.V., Graz, 1954, 9 vols.

\section{Patrologia, coletâneas}

PG: Patrologia Graeca. Migne

GCS: Die Griechischen Christlichen Schriftsteller der Ersten Drei Jahrhunderte. Herausgegeben von der Kirchenväter-Comission der Königl. Preussischen Akademie der Wissenschaften. J.C. Hinrichs'sche Buchhandlung, Leipzig, 1899.

ANF: The Ante-Nicene Fathers. Translations of the Writings of the Fathers down to A.D.325. The Rev. Alexander Roberts, \& James Donaldson, eds. (1885). Revised by A. Cleveland Coxe. Eerdmans Publ. Co., Grand Rapids, 1979. 10 vols.

NPNF: A Selected Library of Nicene and Post-Nicene Fathers of the Christian Church. Ed. Philip Schaff \& Henry Wace. Eerdmans, Grand Rapids, 1952.

\section{Origenes}

Peri Arxon: PG XI, 107-414;

GCS, Origenes V (Koetschau, 1913)

ANF, IV, 239-382

Traité des Principes. Trad. intr. Henri Crouzel e Manlio Simonetti, Ed. Du Cerf, Paris, Souces Chrétiennes, 1978-80, 4 vols.

Contra Celso: PG XI, 637-1632

GCS: Origenes Werke I-II (Gegen Celsus)

ANF: IV, 395-669 (Against Celsus)

Contra Celso. BAC. Madrid

Contra Celsum. Trad. intr. not. Henri Chadwick. Cambridge U.P., 1953

Contre Celse. Trad. intr. not. Marcel Borret. Ed. Du Cerf, Paris, Sources Chrétiennes, 1967-76, 5 vols.

The Philocalia of Origen. Ed. J. Armitage Robinson. Cambridge U.P., 1863.

Homélies sur Jéremie. Trad. Pierre Husson \& Pierre Nautin. Ed. Du Cerf, Paris, Sources Chrétiennes, 1976, 2 vols.

Commentaire sur Saint Jean. Trad. not. Cécile Blanc. Ed. Du Cerf, Paris, Sources Chrétiennes, 1970, 3 vols.

Cantico de los Canticos. Ed. Ciudad Nueva, Madrid.

Prayer. Ed. John O'Meara. The Newman Press. Londres/Westminster. Ancient Christian Writers, 1954, 15-140. 


\section{Comentários}

CADIOU, René. Introduction au système d'Origène. Les Belles Lettres, Paris, 1932.

CORNELLIS, H. Les Fondements cosmologiques de l'eschatologie d'Origène. Revue des Sciences Philosophiques et Théologiques, 43, 1959, 32-80; 201-247.

CROUZEL, Henri. Origène et la Philosophie. Aubier-Montaigne, Paris, 1962.

DANIELLU, Jean. Origenes. Sudamerica, Buenos Aires, 1958.

DUHEM, Pierre. Le Système du Monde. Hermann, Paris, 1988, II volume.

FAYE, Eugène de. Origène, sa vie, son oeuvre, sa pensée. Leroux, Paris, 1923-28.

NAUTIN, Pierre. Origène. Sa Vie et son oeuvre. Beauchesne, Paris, 1977.

\section{Estudos preparatórios}

LUPI, João. A Escola de Alexandria como núcleo do helenismo cristão. Revista de Ciências Humanas. v.11, n.15, março, 1994, 11-23.

A concepção de mundo de Orígenes. Reunião da SBPC, Vitória, 17/22 de julho de 1994, publ. Sumário B.14-008.

A Cosmologia de Orígenes. Pré-publicações do Departamento de Filosofia da UFSC, 26 de agosto de 1994.

Origen on Chance. Relatónio de pesquisa apresentado ao Institute of Medieval Philosophy and Theology, Boston College, 15 de setembro de 1995, 29 pp.

The Meaning of Automaton: Litterary, Religious, and Philosophical.Relatório de pesquisa apresentado ao IMPAT, BC, setembro de 1995, 9 pp.

The Fathers on Syntyxia. Relatório de pesquisa, IMPAT/BC, 31 outubro, 1995, 56 pp.

The Fathcrs on Automaton. Relatorio IMPAT/BC, novembro 1995, 22 pp.

O Significado de Suntuxia em Origenes. Pré-publicaçōes do Departamento de Filosofia, Ano IV, n.36, setembro de 1996, 21pp.

As teorias sobre a ordem do mundo e as doutrinas helenisticas acerca do acaso. Relatório de pesquisa apresentado ao Departamento de Filosofia da UFSC, fevereiro de 1997. 